UDC 622.8

A. E. FILIN1', Associate Professor, Doctor of Engineering Sciences, aleks_filin@bk.ru

O. M. ZINOVIEVA ${ }^{1}$, Associate Professor, Candidate of Engineering Sciences

L. A. KOLESNIKOVA ${ }^{1}$, Associate Professor, Candidate of Economic Sciences

A. M. MERKULOVA ${ }^{1}$, Associate Professor, Candidate of Engineering Sciences

${ }^{1}$ NUST MISIS, Moscow, Russia

\title{
PROSPECTS OF SAFETY CONTROL IN COMBINATION OF MINING AND METALLURGY INDUSTRIES
}

Introduction

Since the earliest days, mining and metallurgy industries are historically interconnected. The qualitative and quantitative composition of ore promoted metallurgical development while new technologies and equipment enabled integrated and efficient processing of low-grade raw materials, which, in turn, favored advancement in mining.

In the USSR, in a planned economy, the industries developed concurrently, which was efficient regarding both governmental supervision and control, personnel training, and safety improvement, etc.

At that stage of development in mining and metallurgy, labor protection and industrial/ecological safety entered the range of the top-priority objectives. New scientific framework was worked out for labor protection and industrial safety, basic legislative and regulatory documents were enacted, public control trade union movement was strengthened, international cooperation was initiated in the area of safety, and foundation was laid for the Sustainable Development Strategy.

The "signature" features of that time were: "zero risk theory" (system of inexorable branch standards to be strictly observed to ensure absolute safety), planned state financing of safety activities, central planning system for production activities (execution of government-set plans, non-competitive conditions, faultless supply and sale, which resulted in the decreased interest of management in safety improvement), etc.

After dissolution of the Soviet Union and transition of government control to market economy principles, high-tech and self-financed branches became private property, which smeared cues of sectorial management. At the present time, it is typical that production resources with different sectorial characteristics are concentrated under control of a single owner.

To day a production owner defines the matters of safety. The owner's culture of safety, reflected in the business philosophy and capital management, basically determines the rates of industrial and ecological safety.

Towards expansion of business, further capitalization of production, profit markup, competitive recovery, strengthening of position in international and domestic markets and business image improvement, an owner strives to amalgamate, stabilize and integrate the entire production process under his own administration. Eventually, quality management is ensured at all stages of production (mining, processing, sales) in accordance with the international standards. Plants and integrated works are joined into large companies and holdings, such as NorNickel, RUSAL, Mechel, United Metallurgical Company (UMK), Metalloinvest and others.

As a result of the complex integration of mining and metallurgy, efficient management of production, including safety, becomes the issue of the day.

This article is aimed to expose aspects, problems and possible solutions in the area of safety in the integrated mining-and-metallurgy industry.

\section{Production and ecology-related features of safety in mining-and-metallurgy}

Mining and metallurgy industries have created and operate, in a varying degree, systems of labor protection, production safety and environment preservation management. For instance, in the mining industry, in 2016, as per official statistics of Rostekhndazor (Federal Environmental, Industrial and Nuclear Supervision Service of Russia), industrial safety management systems were introduced at 583 out of 608 mines, which made $97 \%$ [1].

Companies align management systems in conformity with the international standards ISO 9001, OHSAS 18001 and ISO 14001 [2-4]. The listed documents impose general requirements on management systems for organizations of any type and size, irrespective of geographical, cultural and social differences.

When creating a management system, an organization is faced with the absence of a common methodological framework taking into account specific nature of mining-and-metallurgy. Many aspects remain fuzzy in practical application. What is specifically understood as hazard or ecological aspect? How exactly a hazard should be identified, or risk should be assessed? What are the principles to evaluate significance of 


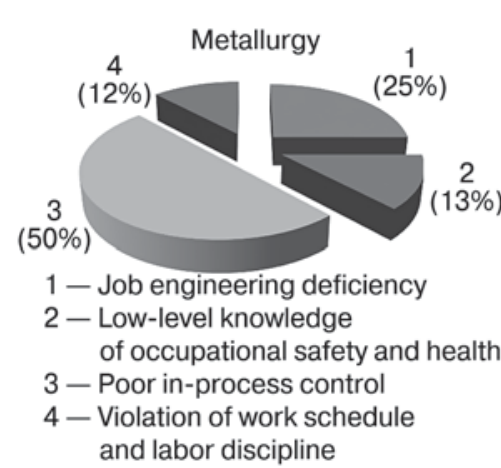

$31 \%$ of workers are engaged in back-breaking labor [8].

In mining, occupational hazards are distributed similarly. More than $66 \%$ of employees work in harmful and/or hazardous conditions. Over $38 \%$ of workers are exposed to noise; over $19 \%$ - to fibrogenic aerosols; over $17 \%$ - to vibrations; round $10 \%$ - chemical action; $7 \%$ - microclimate; $5 \%-$ photic environment, etc; $35 \%$ - back-breaking labor [8].

Explosion hazards, pressurized equipment and chemically toxic substances are the pre-requisites of typical accidents in production processes. Large-scale turnover of substances and materials, considerable consumption of material assts, high energy intensity and environmental attack make the risk, and to propose risk management activities? And so on. All these problems are addressed by each company individually, according to comprehension and qualification of executives.

For example, all companies develop procedures for risk identification and management based on numerical score and ratings [5]. In the meanwhile, registry of risks and hazardous situations, principles of scoring, proficiency of experts, input data for decision-making and control measures are different even inside a single large company, and the information is complex and requires automated processing $[6,7]$. All these circumstances contribute to a decrease in efficiency of control. As a consequence, under formal compliance with the standards sufficient for certification, the key target - higher safety - is missed.

According to Rostekhnadzor's statistics in 2016, the major causes of accidents and injuries remained situations amendable with the efficient management (Fig. 1) [1].

The most critical element is the ecological safety. In the modern world reality, specifically when business is oriented both to the domestic and international markets, it is impossible to go without an environmental management system. It can be very difficult to identify ecological aspects and reveal all elements and processes potentially harmful for the environment. A soon as revealed, these aspects should be controlled, analyzed and mitigated.

Further complexities arise when a company owner is changed as it is required to integrate a new productive object in the existing management system.

It seems relevant to create unified methodological approaches developed by scientific community jointly with competent and skillful production workers from mining and metallurgy, with regard to the best international practices.

The hazards in mining and metallurgy are in many ways identical. Dustiness and gas pollution of working zone air, increased levels of noise and vibration, or moving machines accompany all stages of ore conversion to metal.

On evidence of the Federal State Statistics Service of Russia, more than $60 \%$ of workers in metallurgy have harmful and hazardous jobs. As per the working environment factors, round $40 \%$ of workers are exposed to noise; $20 \%$ - to chemical attacks; $18 \%$-to fibrogenic aerosols; up to $14 \%$ - microclimate; 10 - photic environment; more than $7 \%$ - vibration, etc. Over mining and metallurgy industries hazardous and difficult to control.

Similar nature of hazards dictates similar principles of counteraction. The current methods and means of protection - organizational, technological, hygienic and individual - are also alike in mining and metallurgy. Ventilation, electrosafety, explosion protection as well as mechanical control and trauma protection are used in both industries [9]

Indisputably, despite similarity, mining and metallurgy have distinguishing features of industrial safety, e.g., chemistry and size distribution of dust, thermal effect, work environment dimensions, application of process and protection equipment, scale and difficulty of emergency response, etc. These differences should be taken into account in development of unified hazard registers, risk assessment procedures, protective measures and other safety methods and means towards efficient management within the vertically integrated mining-and-metallurgical companies (holdings).

Environmental concerns due to operation of mining-andmetallurgical integrated works are similar, too, since they are governed by composition of ore and rocks, as well as their mining, pre-treatment, processing and haulage technologies. The ecological problems have complex character. The complexity means that production flows involve all basic propagation chains of pollutants: air (crushing, pretreatment, processing and waste storage) and water (water removal, discharge from tailings ponds, processing effluents). For metallurgical plants and open pit mines, air propagation problems are of particular concern [10].

All methods of mineral mining have influence on biosphere and affect almost all its elements: air and water basins: earth, subsoil, flora and fauna.

According to the data of Academician V. A. Chanturia, in the recent 20 years, the content of nonferrous metals in ore reduced 1.3-1.5 times, iron -1.25 times and gold -1.2 times while portion of rebellious ore increased from 15 to $40 \%$ of the total mass of feedstock in processing. As a consequence, mining waste grow. Nonferrous metallurgy mines in Russia and the CIS countries have accumulated tens billion tons of overburden, billion tons of tailings and hundred tons of metallurgical slag. 
In Russia, extensive research has been carried out toward prevention of the environmental impact of mining and metallurgy. Eventually, large packages of measures on labor protection and sound management of natural resources are developed in the mineral mining industry. For example, Development Strategy for Extreme North Territories and Equivalent Lands provides a number of major investment projects connected with creation of new transport routes, as well as with mining operations in large Timan-Pechora oil and gas province and at hydrocarbon deposits on the continental shelf of the Barents and Pechora Seas. A good example is Gazprom. The NordStream gas transmission project eminently accounts for the distinguishing features of the Baltic region. During the project implementation, ecology priority has become the governing factor of ecological security and environmental protection in the course of the Bovanenskoe oil and gas condensate field development on the Yamal Peninsula. Discharge of wastewater to watercourses is completely eliminated; radial gas discharge in well clusters and a series of technological activities aimed at considerable reduction on green gas emission are provided; special engineering solutions are developed towards waste disposal safety. The project pays much attention to preservation of stable permafrost conditions.

During development of oil and gas fields on the continental shelf (Prirazlomnoe oil and Shtokman gas condensate), special ecological and fishery standards were worked out for geological exploration and extraction of hydrocarbons in the Eastern Kamchatka subsoil. In all projects, waste is subjected to maximum possible recycling and coastal disposal, and an oil spill response system is created. This example illustrates feasibility of success in integration of different productions. However, mining-and-metallurgy industry is behind with safety control efficiency despite their similar characteristics of extended transportation systems, difficult operating conditions and many others.

It is currently impossible to undertake qualitative and quantitative comparative assessment of the environmental impact of mining-and-metallurgy and other anthropogenic activities owing to the lack of a scientific-and-methodological framework. The application of different partial criteria offers no unambiguous outcome.

Mining industry drastically affects biosphere, including all its elements, with most sever attack on water, ground surface and subsoil. Metallurgy has major influence on air [11] and surface water.

Comparison of absolute cost of sewage works construction in nonferrous and ferrous metallurgy, heat-power engineering and mining industry in USA shows that the highest expenses fall at the heat-power engineering. In terms of relative share of this cost in total investment, nonferrous metallurgy takes the first place.

With respect to total expenditure connected with antipollution in USA, first goes paper-and-pulp industry, then follows power engineering and ferrous/nonferrous metallurgy. At the same times, these criteria miss some aspects of direct and indirect influence of mining-and-metallurgy on the environment and, thus, cannot be assumed as a sufficiently objective [12].

\section{Personnel training for mining-and-metallurgy}

A distinct trend in the sphere of mining-and-metallurgy safety improvement is skillful personnel training [13, 14]. Education standards should ensure formation of competences with regard to the current engineering links. At the present day, large companies need professionals both in mining and metallurgy.

Training of competent staff for mining and metallurgical industries has been carried out over 100 years in Russia. Over that period, mining and metallurgy education branches grew and expanded concurrently and, eventually, were fused into the National University of Science and Technology (MISIS) in 2014. This day, after integration of education and research activities, multilevel training of specialists in mining and metallurgy is implemented in one spot.

Authorized to develop proprietary educational standards, the University prepares Bachelors and Masters of Engineering as well as advanced students, and offers additional training. As a part of graduate qualification and dissertation papers, researches are being carried out for the mining-and-metallurgy industry. In particular, MISIS cooperates with the leading mining-and-metallurgical companies, which allows practical training of students, scientific work, additional and advanced training (full-time, distance and on-line learning). Academic curriculums are being improved now with a view to introducing mining and metallurgical disciplines sufficient to shape the required scope of functions for the efficient and successful work at mining-and-metallurgical companies.

For instance, the Gubkin division of MISIS starts training of Bachelors in Technosphere Safety, and the related academic curriculum includes mining and metallurgy disciplines. The mission is to provide mining-and-metallurgical companies with high-skilled personnel.

Training of Masters in safety includes such mining-andmetallurgy disciplines as characteristics of mining-and-metallurgy effect on technosphere, integrated systems of safety control, elaboration of safety aspects in projects, etc.

The highest qualification personnel training is also subjected to integration. At the moment, joint dissertation councils for theses defense for the Degrees of Candidate and Doctor of Science in the branches of Labor Protection and Industrial and Fire Safety in the mineral and metallurgical industries are being formed. MISIS College of Lifelong Learning and Chair of Technosphere Safety implement additional education programs including mining and metallurgy modules and blocks. Nearby urban plants, institutions of education in the related areas of expertise are founded, and classes are organized so that to embrace all levels of training, including lecturers. It is anticipated to attract high-level professionals in pedagogy and science from the top universities of Russia, which proves the currentness of the problem connected with harmonization of industrial clusters on-site.

In this manner, to establish a foundation for the further efficient advancement in the mining-and-metallurgical industry, it is required to harmonize productive-economic clusters of mining and metallurgy, uniting diverse elements with the shared objective. Such elements are, for instance, processes 
and equipment, logistics, skillful personnel training, latest achievements in science and technology, international experience, automation and digitization of production, etc. [15]. Meanwhile some problems connected with the integration of the two industries are solved by owners, production safety matters remain discrete and uncovered.

At the present day, an owner of a large mining-and-metallurgical integrated works, in order that business is efficient and safe, needs to function within a conjoint mining-and-metallurgy field of legislative/regulatory documents and unified protection standards, and to attract highly skilled personnel with sufficient knowledge both in mining and metallurgy, as well as to use the related scientific and methodological framework.

\section{Conclusion}

Finally, based on the aforesaid, it can be stated that:

1. Being based on economic efficiency, the general trend of integrating different productions inevitably results in industrial clustering. In particular, de-facto the mining-andmetallurgical industry in Russia has already formed a core of such major productions as mineral mining, pretreatment and high-level processing, metallurgy, sales at various stages of production and intricate logistics.

2. The current basic production processes in these clusters are yet incapable to execute efficient control over a number of functions. The problems of labor, production and ecology safety are not always sufficiently qualitatively solved, which calls for a system approach to management at the level of scientific research and education.

3. Research and education should generate unified standards of efficient production control within industrial clusters in the form of consolidated norms from various types of production as well as through training of personnel having wider knowledge and being competent in terms of safety in both industries.

4. Considering difficulties of forming integrated competences in different industries and areas of safety, the process of education should communicate with research institutions and production practices both in terms of hand-on experience and decision-making.

5. Far-embracing association of production-related teaching resources of research-and-education centers in large cities and smaller towns will make it possible to solve such problems of industrial clusters as higher quality process-specific personnel training using a wider range of scientific, educational and applied means. Moreover staffing structures will become able to more effectively attract specialists as students will get a deeper insight into the production in process of training and will more soundly select place of employment. In turn, the industry can purposedly and more potently maintain education process as well as funda- mental and applied research, and superintend human resources.

6. The proposed approach is intended to meet the present-day challenges of large holdings and corporations thanks to more efficient management of productive processes within an industrial cluster owing to integrated formation of basic resources.

References

1. Available at: http://www.gosnadzor.ru/public/annual_reports (accessed: 28.03.2018).

2. ISO 9001-2015 Quality management systems. Requirements (IDT). Moscow : Standartinform. 2015.

3. OHSAS 18001-2007 Occupational health and safety management systems. Requirement. Moscow : Standartinform. 2012.

4. ISO 14001-2015 Environmental management systems - Requirements with guidance for use (ITD). Moscow : Standartinform. 2015.

5. Zinovieva O. M., Mastryukov B. S., Merkulova A. M. Industrial risk management in metallurgy. Proceedings of All-Russian ScientificPractical Conference devoted to the 20th anniversary of the Federal Law on Industrial Safety of Hazardous Production Objects. Moscow: Nauchno-tekhnicheskii tsentr issledovanii problem promyshlennoi bezopasnosti. 2017. pp. 206-209.

6. Ivashchuk O., Konstantinov I. Approaches to creating environment safety automation control system of the industrial complex. Proceedings of the 7 th International Conference on Intelligent Data Acquisition and Advanced Computing Systems (IDAACS). Berlin, Germany. 2013. Vol. 2. pp. 828-832.

7. Kudryavtsev S. S., Yemelin P. V., Yemelina N. K. The development of a risk management system in the field of industrial safety in the Republic of Kazakhstan. Safety and Health at Work. 2018. Vol. 9. Iss. 1. pp. 30-41.

8. Available at: www.gks.ru/wps/wcm/connect/rosstat_main/rosstat/ru/statistics/publications/catalog/ (accessed: 28.03.2018).

9. Filin A. E. Prospects of mining industry safety. Izvestiya vuzov. Gornyi zhurnal. 2016. No. 5. pp. 31-33.

10. Kolesnikova L. A. Environmental conditions in mining regions. Ugol. 2017. No. 4. pp. 68-69.

11. Mastryukov B. S., Merkulova A. M. Accidental emissions in the metallurgical industry and specifics of their propagation. Metallurgist. 2009. Vol. 53. Iss. 1-2. pp. 3-9.

12. Mihelcic J. R., Naughton C. C., Verbyla M. E., Zhang Q., Schweitzer R. W., Oakley S. M., Wells E. C., Whiteford L. M. The grandest challenge of all: the role of environmental engineering to achieve sustainability in the world's developing regions. Environmental Engineering Science. 2017. Vol. 34. No. 1. pp. 16-41.

13. Mastryukov B. S., Zinovieva O. M., Merkulova A. M., Smirnova N. A. Additional training of students, specialists and leadership of educational institutions in the sphere of life activity safety in emergency situations. Bezopasnost zhiznedeyatelnosti. 2009. No. 2. pp. 47-51.

14. Díaz-de-Mera-Sancheza P., Gónzalez-Gayab C., Moralesb F., Rosalesb V. Strengthening Competencies in Learning of Industrial Safety Focused on Projects. Procedia Engineering. 2015. Vol. 132. pp. $183-189$.

15. Myaskov A. V. The future of mining engineers: interdisciplinary and digitization work. Gornyi Zhurnal. 2018. No. 2. pp. 13-17. 